\title{
The Importance of Innovation in Entrepreneurship for Economic Growth and Development. A Bibliometric Analysis
}

Adriana DIMA ${ }^{1}$

Abstract
The evolution of entrepreneurship in recent years offers strong
arguments regarding the role of entrepreneurial initiatives to stimulate
economic growth and development and innovation has proven an essential tool
for entrepreneurs. The objective of the current research is to present a
bibliometric perspective of the relevant literature. The field structure is defined
using bibliometric indicators, and the key trends in this area are mapped using
the VOSviewer program. Over the period 2000-2020, a total of 958 papers
were found in the Web of Science Core Collection database regarding the
importance of innovation in entrepreneurship for economic growth and
development. A careful review of the articles, conference papers, authors,
institutions, and keywords is performed. Also, the co-occurrence of keywords
and timeline review are presented. Finally, the paper provides relevant
conclusions on the topic.

Keywords: co-occurrence, economic growth, economic development, entrepreneurship, innovation, keywords map, VOSviewer.

JEL classification: $\mathrm{C} 88, \mathrm{M} 21, \mathrm{O} 10$

DOI: $10.24818 /$ RMCI.2021.1.120

\section{Introduction}

Entrepreneurship represents a fundamental factor of economic evolution, but also an important factor of unequal economic development of regions and nations (Teixeira, 2018; Yun, J. J., Won, D., \& Park, K. (2018). In fact, entrepreneurship is a key element of the evolutionary economy (Stam \& van de Ven, 2019) and an important point in economic development (Malecki, 2018; Cho \& Lee, 2018).

The association of entrepreneurship with economic performance has a well-established foundation. Economies stimulate entrepreneurial activity, which is oriented towards the demands of the market, with real successes in terms of economic performance and prosperity. Entrepreneurship is important for the development of the economy. The benefits and results are clearly seen in countries where bureaucracy is small, entrepreneurs' taxes and fees are low and the state encourages the opening of new companies through financial support (Trifu,

\footnotetext{
${ }^{1}$ Bucharest University of Economic Studies, Adriana.dima@man.ase.ro
} 
Gîrneață \& Potcovaru, 2015). If a country does not provide a favorable environment for entrepreneurial development, entrepreneurs move to countries where this is stimulated (Gîrneaţă \& Mascu, 2014; Dhahri \& Omri, 2018).

Entrepreneurship is a key factor in prosperity, but it can divert productive entrepreneurial efforts when freeing business people from the demands of the market. The development of some countries, respectively the impoverishment of others, cannot be analyzed as causes of excess or deficit of entrepreneurship, while entrepreneurship is seen as the ability of individuals to innovate and create profit.

In the context of the extremely fast pace of change that characterizes the economic and social environment, the capacity for innovation becomes a vital feature of any organization. Innovation appears as a key term in the mission or value statements of many companies and organizations. However, it is often difficult for managers at different organizational levels to put innovation into practice, to transform it from an intangible goal into a series of concrete, impactful actions.

\section{Literature Review}

The evolution of entrepreneurship in recent years offers strong arguments regarding the role of entrepreneurial initiatives to stimulate economic growth and development (Sergi et al., 2019; Chen et al., 2018). Globally, small and mediumsized enterprises generate most of the added value in the private economy, concentrate more than half of the workforce employed in the private economy and play an important role in creating added value in research and innovation in the top fields: IT, nanotechnology, genetics, astrophysics, invention (Kim, ElTarabishy \& Bae, 2018).

Previous research led to the conclusion that small and medium-sized enterprises represent the closest profile of the knowledge-based enterprise, as they have a small number of employees, but have a high level of professional training, have state-of-the-art technology and technology, and the main resource and development factor is the knowledge and information held (Bolukbas \& Guneri, 2018). An important vector for the growth of new formed enterprises is innovation. More and more companies are moving towards innovative measures and the use of advanced technology in their business operations, to increase their chances of success in the market and to achieve increasingly high levels of efficiency. Viable solutions for sustainable growth can be found in research and development, strategic analysis of the economic environment (Trifu, Girneata \& Potcovaru, 2014) and the use of new technologies and innovative techniques, and in the business environment innovation leads to increased performance of goods and services offered, increases competitiveness and generates new markets and activities with a high degree of added value (Abbas \& Sağsan, 2019). Taking into account these premises, it is necessary that the study of entrepreneurship and its impact on economic growth and development be deepened.

Review of International Comparative Management

Volume 22, Issue 1, March 2021 
In a broad sense, entrepreneurship is the process of creating and developing a business on its own, based on entrepreneurial talent, skills and abilities to perceive and capitalize on market opportunities (Shu, Ren, \& Zheng, 2018).

Entrepreneurship can be defined as a person's ability to seize a business opportunity based on natural talent and acquired skills, by allocating necessary resources and overcoming risks or other difficulties that may arise. Some experts say that entrepreneurship is mainly the result of an accumulation of traits acquired as a result of the knowledge and information gained, as well as the experiences gained (Dias et al., 2020). Other consider that the formation and manifestation of entrepreneurship is influenced by a number of factors, some of which representing the intrinsic characteristics of the entrepreneur or future entrepreneur, but the highest importance is held by internal variables - those that belong exclusively to the individual (Kibler et al., 2019).

Elliott, Mavriplis and Anis (2020) state that those individuals who have some experience and a high level of education will be much more receptive to technological changes in society and therefore will have a higher capacity to seize an entrepreneurial opportunity. Moreover, it is considered that entrepreneurs perceive business opportunities due to the knowledge and information acquired, through which they form an ability to identify market opportunities that other people do not possess. Thus, entrepreneurship can be formed, entrepreneurship education in pre-university and university programs being a factor in accelerating entrepreneurship.

The entrepreneur has the potential to grow the business to become a much larger enterprise, and for that it is important to think about every step of development. Entrepreneurs need to know and analyze very well the business environment in which they want to operate. Micro and macro analysis of the business environment are two things that underlie the development of a business. The launch of a product or service in the business environment will be validated by customers. They are the ones who make the product or service a success or a total failure.

Most entrepreneurs aim to maximize their chances of success before embarking on a time, money and energy consuming process. Above risk and motivation, most future entrepreneurs see the development of a business as a solution for a more prosperous life and increased income. However, the notion of entrepreneurship has changed as new types of entrepreneurs have emerged who have defined success in their own terms. There are entrepreneurs who are employed full time, and in their free time they develop their own business.

A major discrepancy can be observed in the performance of newly established companies between Western and Eastern Europe. Countries with a low level of GDP per capita have a national economy based on the existence of a large number of small firms. If the GDP/capita indicator increases, large firms can afford to meet increased market demand and make investments and industrializations that lead to a growth of the economy. There is an inversely proportional relationship 
with large and small firms. If an increasing number of people find a stable and well-paid job, this will lead to a decrease in the establishment of new small companies, and this will lead to an increase in the opportunity cost of possible decisions on starting a new start-up.

Demographic characteristics are important and influence entrepreneurship. In countries where young people are predominant, a much more pronounced development of new companies can be observed, while in a country where the majority of the population is older, there is less interest in opening a business.

Innovation is an essential tool for entrepreneurs. They notice a need in the market and take this opportunity to create or improve products or services. If the entrepreneur is creative and innovative, he will be able to develop products and services adapted to a target audience. However, the innovation process is being built and improved by the entrepreneurs involved in the business. In very few cases an innovative idea is developed entirely by the entrepreneur. Sometimes it doesn't even matter how well the idea is articulated, it must be analyzed and modified, sometimes even radically, in order to be put in a business plan, which can generate financing. Entrepreneurs will cross many barriers to apply the business idea. Understanding these barriers can make the innovative idea more predictable.

Innovation is defined in the literature in various ways, but they are based on the same core, namely a creative thinking that creates value (Table 1).

Table 1. Various definitions of innovation in recent literature

\begin{tabular}{|c|c|}
\hline Authors & Definition of innovation \\
\hline Tidd \& Bessant (2020) & $\begin{array}{l}\text { Innovation is a process through which opportunities turn into } \\
\text { ideas put into practice }\end{array}$ \\
\hline $\begin{array}{l}\text { Schilling \& Shankar } \\
(2019)\end{array}$ & The way an idea is implemented in a business process \\
\hline Verdin \& Tackx (2015) & Creating a new value in a creative way \\
\hline Katzy et al. (2013) & $\begin{array}{l}\text { Marketing a product, service, process or idea or changes to } \\
\text { existing products }\end{array}$ \\
\hline $\begin{array}{l}\text { Baregheh, Rowley \& } \\
\text { Sambrook (2009) }\end{array}$ & $\begin{array}{l}\text { A multi-stage process by which companies turn their ideas into } \\
\text { products, services or processes in order to have an advantage } \\
\text { over the competition and the market }\end{array}$ \\
\hline $\begin{array}{l}\text { Carlson \& Wilmot } \\
\text { (2006) }\end{array}$ & $\begin{array}{l}\text { The process by which an idea becomes valuable to customers } \\
\text { and produces a sustainable profit for the company }\end{array}$ \\
\hline Porter \& Stern (2001) & Transforming knowledge into products, services or processes \\
\hline
\end{tabular}

Innovation refers to aspects such as the development of new products, websites, new production processes, new business models, new strategies, new services, new solutions to new problems and much more. Creative people, who think about the future, are the ones who make their mark and move forward. It is often risky for future entrepreneurs to try new things or propose new approaches, but it is even more risky to stay in the comfort zone and not act on the changes around them. Innovation must be part of the daily routine, because the market is 
evolving so fast that it is very easy to get out of it. Innovation and the way it is achieved at the level of organizations is a topic that has preoccupied both the business and the academic environment for a long time. However, there is no generally valid method, procedure or recipe for tackling the innovation process.

\section{Research Methodology}

The aim of this research is to assess how the connection between innovation, entrepreneurship, economic growth and development is illustrated in the literature, by the instrumentality of the bibliometric technique. The proposed bibliometric analysis was conducted after a careful selection of papers in the Web of Science Core Collection database, which was chosen due to the quality of the information provided and to the importance of the studies published here. Bibliometrics uses quantitative and statistical approaches to examine trends that occur in the publication and communication of documents. Through delivering structural analysis, it offers a systematic, straightforward and reproducible study of a wide body of knowledge. For the purpose of research assessment, bibliometric techniques are used by various researchers in different fields: management (Gaviria-Marin, Merigó \& Baier-Fuentes, 2019; Vallaster et al., 2019, Gora, 2019), marketing (Kim, Kang, \& Lee, 2019), healthcare (Tran et al., 2019) artificial intelligence (Dhamija \& Bag, 2020) and many others.

Using the bibliometric technique, the current paper proposes the following research objectives:

- Study of the primary subject area concerned with the concepts of innovation, entrepreneurship, economic growth and development;

- Review of papers published each year in order to assess the growth rate and geographic dispersion of literature articles on the selected topics;

- Study of the quotations acquired from these publications;

- Examination of and visualization of keywords in the form of a diagram, grouped into clusters.

Therefore, the foregoing steps have been taken in this research paper:

(1) The first step was to search for four main keywords chosen for analysis, "innovation", "entrepreneurship", "economic growth" and "development" in the Web of Science database, using the connector 'and' between them. This selection generated 1,101 papers.

(2) The following step was limiting the publication year of the selected papers to the period $2000-2020$ and this generated 1,093 papers.

(3) The third step implied filtering the selected research by document type. The following were selected: articles, books, book chapters, reviews and conference papers (the options EARLY ACCESS and EDITORIAL MATERIAL were eliminated). As a result, 1,049 documents were included in the list.

(4) The final phase involved refining the results based on the subject area of the papers. Here, there were selected the Web of Science categories 
with more than five publications and the resulting list contains 958 documents which were analyzed in this research.

The remaining 958 documents were further analyzed using VOSviewer, a computer program that creates, visualizes and explores bibliometric maps of science in order to obtain the following objectives:

a) analysing the selected papers to illustrate the total number of papers by year and by country in the field of innovation, entrepreneurship, economic growth and development and presenting the research distribution on journals and conference volumes;

b) analysing the keywords and illustrating the co-occurrence and the established links between them.

\section{Findings}

Initially, an analysis was made on the most important types of research that tackle the analysis of the importance of innovation in entrepreneurship for economic growth and development. Based on the information taken from the Web of Science Core Collection, it can be seen that articles and proceedings papers are the most common publications that address the topics analyzed. The two account for over $95 \%$ of the total number of publications (Figure 1). This is due to the fact that the field analyzed is a relatively recent one, and articles and communications in conferences are published much faster than chapters or books.

The novelty aspect is also reflected by the number of researches carried out in the last years, compared to the beginning of the 2000s. Based on the information available in the Web of Science Core Collection, the distribution of the number of publications in the last 20 years was made. In 2000, no publication was registered to cover the analyzed concepts and therefore this year is not listed in Table 1.

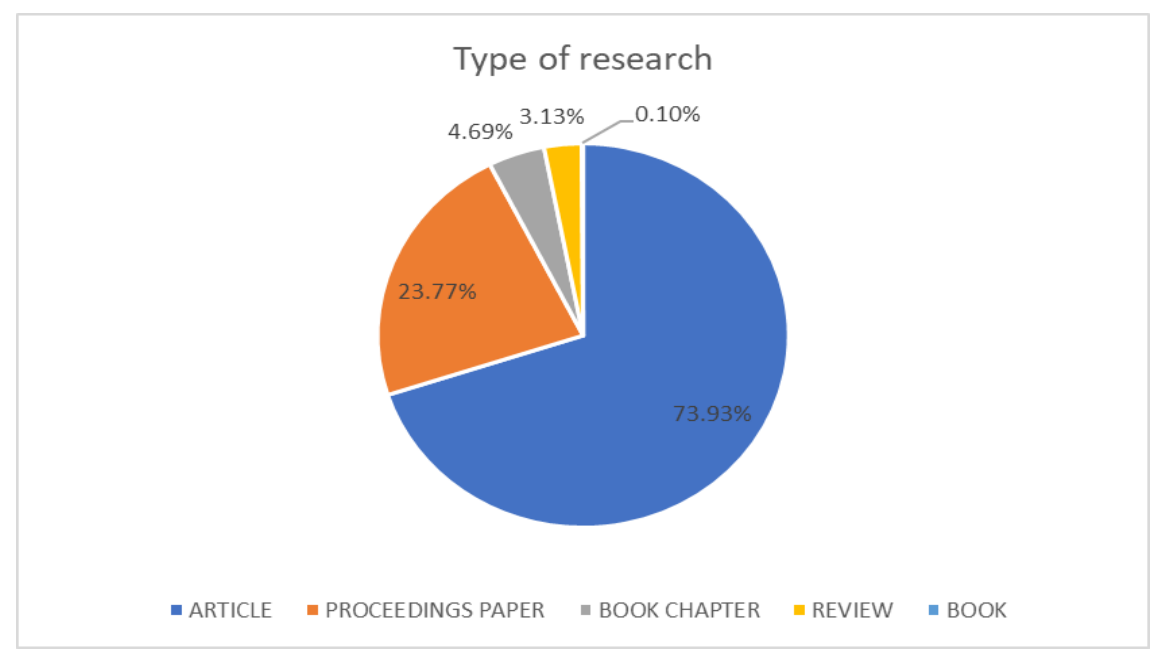

Figure 1. Type of research

Source: authors after Web of Science Core Collection 
It is obvious the appetite of researchers for this field in recent years, because since 2017 more than 100 papers have been published in each year. Thus, in the last five years, more than $50 \%$ of all publications addressing concepts such as innovation, entrepreneurship, economic growth and development have been published.

Table 1. Research distribution between 2000-2020

\begin{tabular}{|l|l|l|l|l|l|}
\hline $\begin{array}{c}\text { Publication } \\
\text { Year }\end{array}$ & $\begin{array}{c}\text { Number of } \\
\text { publications }\end{array}$ & $\begin{array}{c}\text { Percentage } \\
\text { of total }\end{array}$ & $\begin{array}{c}\text { Publication } \\
\text { Year }\end{array}$ & $\begin{array}{c}\text { Number of } \\
\text { publications }\end{array}$ & $\begin{array}{c}\text { Percentage } \\
\text { of total }\end{array}$ \\
\hline 2020 & 104 & $10.856 \%$ & 2010 & 41 & $4.280 \%$ \\
\hline 2019 & 130 & $13.570 \%$ & 2009 & 19 & $1.983 \%$ \\
\hline 2018 & 123 & $12.839 \%$ & 2008 & 23 & $2.401 \%$ \\
\hline 2017 & 102 & $10.647 \%$ & 2007 & 8 & $0.835 \%$ \\
\hline 2016 & 87 & $9.081 \%$ & 2006 & 5 & $0.522 \%$ \\
\hline 2015 & 80 & $8.351 \%$ & 2005 & 13 & $1.357 \%$ \\
\hline 2014 & 66 & $6.889 \%$ & 2004 & 6 & $0.626 \%$ \\
\hline 2013 & 65 & $6.785 \%$ & 2003 & 1 & $0.104 \%$ \\
\hline 2012 & 48 & $5.010 \%$ & 2002 & 3 & $0.313 \%$ \\
\hline 2011 & 33 & $3.445 \%$ & 2001 & 1 & $0.104 \%$ \\
\hline
\end{tabular}

Source: authors after Web of Science Core Collection

Next, the most important categories in the Web of Science Core Collection were analyzed, under which more than 20 publications were published (Figure 2). Thus, the main categories of interest proved to be business, management and economics, which aim at the management and economic aspects of an organization.

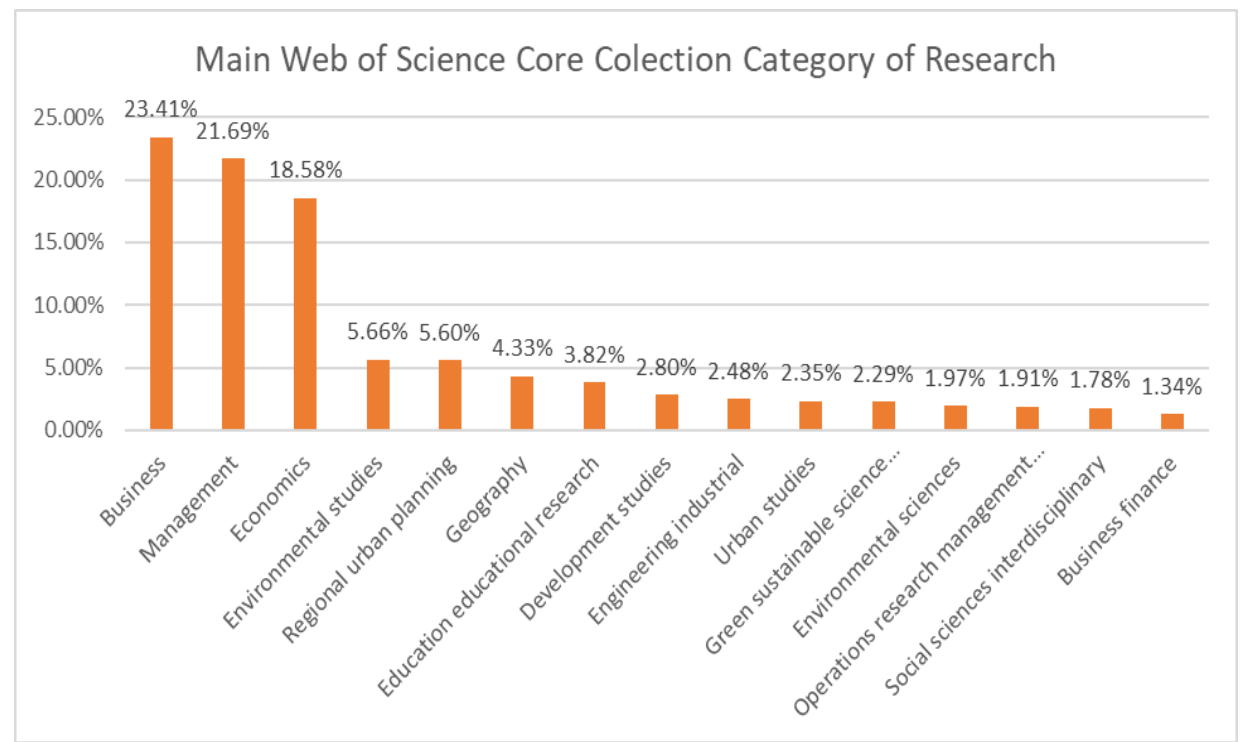

Figure 2. The main Web of Science Core Collection categories Source: authors after Web of Science Core Collection 
The importance given by the regions of the world to the aspects related to innovation in entrepreneurship for economic growth and development is also reflected by the number of publications resulting from the research carried out in the respective states. Based on the centralized information from the Web of Science Core Collection, it is found that the 10 most prolific states in terms of the number of publications targeting the mentioned fields include the main economic poles of the world, such as USA, China, Germany, but also smaller states like Portugal, Romania or Sweden.

Table 3. First 10 most influential countries or regions of research

\begin{tabular}{|l|l|l|}
\hline \multicolumn{1}{|c|}{ Country/Region } & Number of publications & Percentage of total \\
\hline USA & 174 & $18.163 \%$ \\
\hline ENGLAND & 86 & $8.977 \%$ \\
\hline SPAIN & 76 & $7.933 \%$ \\
\hline CHINA & 66 & $6.889 \%$ \\
\hline GERMANY & 62 & $6.472 \%$ \\
\hline ITALY & 51 & $5.324 \%$ \\
\hline NETHERLANDS & 47 & $4.906 \%$ \\
\hline PORTUGAL & 41 & $4.280 \%$ \\
\hline ROMANIA & 38 & $3.967 \%$ \\
\hline SWEDEN & 38 & $3.967 \%$ \\
\hline
\end{tabular}

Source: authors after Web of Science Core Collection

The most influential publishers were further analyzed in Table 4. It is found that most research on innovation, entrepreneurship, economic growth and development has been published in journals such as Small Business Economics, Sustainability and Journal of Technology Transfer, but also as dissemination of results within The European Conference on Entrepreneurship and Innovation. Therefore, the most important publisher addresses issues related to SMEs, businesses focused on innovation, entrepreneurship and economic development.

Table 4. First 10 most influential publishers

\begin{tabular}{|l|l|l|}
\hline \multicolumn{1}{|c|}{ Publisher } & \multicolumn{1}{|c|}{$\begin{array}{c}\text { Number } \\
\text { of publications }\end{array}$} & $\begin{array}{c}\text { Percentage } \\
\text { of total }\end{array}$ \\
\hline Small Business Economics & 37 & $3.862 \%$ \\
\hline $\begin{array}{l}\text { Proceedings of The European Conference on } \\
\text { Entrepreneurship and Innovation }\end{array}$ & 26 & $2.714 \%$ \\
\hline Sustainability & 26 & $2.714 \%$ \\
\hline Journal of Technology Transfer & 21 & $2.192 \%$ \\
\hline Technological Forecasting and Social Change & 17 & $1.775 \%$ \\
\hline Entrepreneurship and Regional Development & 16 & $1.670 \%$ \\
\hline Regional Studies & 16 & $1.670 \%$ \\
\hline Economic Development Quarterly & 12 & $1.253 \%$ \\
\hline European Planning Studies & 11 & $1.148 \%$ \\
\hline Journal of Business Research & 11 & $1.148 \%$ \\
\hline
\end{tabular}

Source: authors after Web of Science Core Collection 
The following section of the paper aims to define the most common keywords used to categorize papers about innovation in entrepreneurship for economic growth and development and to pinpoint the most commonly occurring topics in the field. The indexed and authors' keywords were used to continue the study.

In the selected sample (958 papers), the keywords which appeared less than 80 times were eliminated to illustrate solely the keywords in the field that have a greater significance. In VOSviewer, these are utilized to represent the keyword network (Van Eck \& Waltman, 2013). The outcome of running the VOSviewer algorithm with a minimum of 80 keyword occurrences is shown in Figure 3. The weight of the nodes (keywords), i.e., occurrences, is defined by the size of the nodes and words.

The distance between two nodes indicates the strength of their relationship, a shorter distance indicating a stronger connection. The network connections reveal the keywords that appear together in the analyzed publications more frequently. A line connecting two keywords signifies that it exists a co-occurrence and the higher the co-occurrence frequency, the thicker the line. Also, the node's color reflects the total number of publications each year for that node. This indicates how keywords have evolved over time (2000 - 2020).

The blueness nodes are attributed to keywords that were used earlier in the research period, while the green and yellow nodes refer to keywords that were used in more recently published papers. It is worth noting that the terms growth, economy, entrepreneurship and innovation are found in the middle of the scale due to their recurrence during the study period.

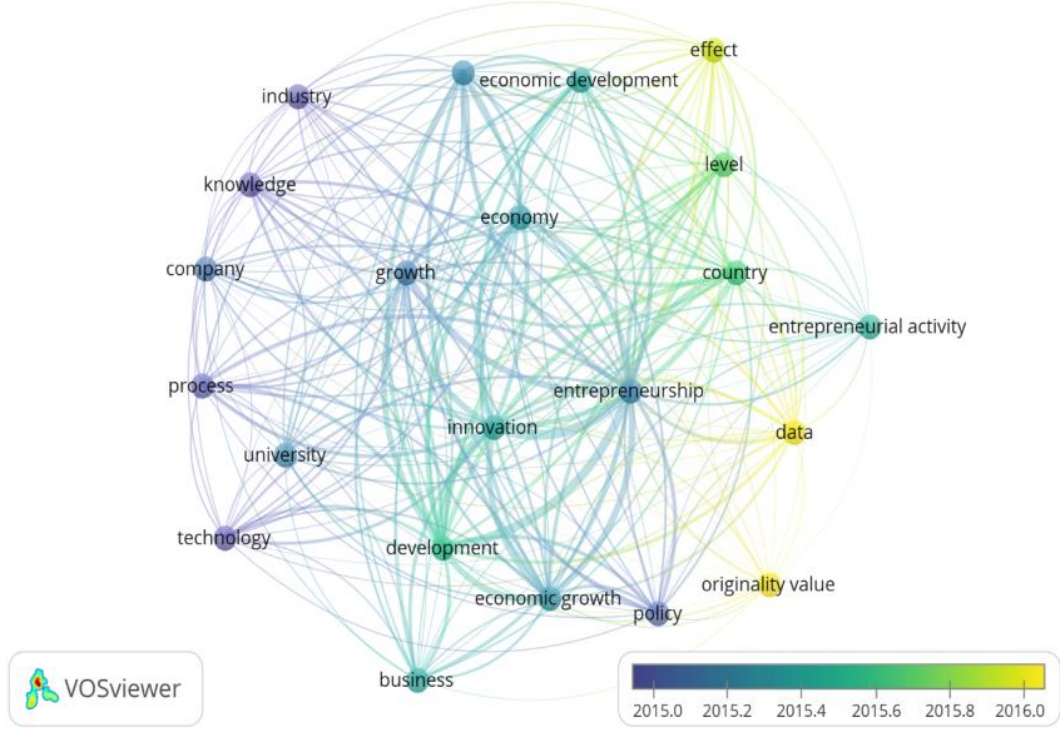

Figure 3. Mapping links between keywords in time Source: authors with VOSviewer 
The main conclusions that emerge from this analysis are that at the beginning of the analyzed period the number of publications analyzing the targeted field was quite low, which led to a limited number of links between keywords, which did not appear in the analysis. Subsequently, after 2015, due to the increase in the incidence of articles, there were several connections between keywords such as industry, knowledge, company, process, university, technology, policy, business, economic development, economic growth, entrepreneurial activity. The most recent publications have as keywords: level, country, effect, data or originality value. It is important to mention that the number of publications can easily increase, because for the period 2000 - 2020 the conferences were also taken into account; some of these can be indexed later and can be seen in the ISI database after the analysis is completed.

Apart from observing how the main keywords have evolved, this process is important for researchers who can easier select the correct keywords to explain their papers and therefore increase their visibility.

\section{Conclusion}

The aim of this paper is to help scholars to have a wide perspective of the link between innovation and entrepreneurship in generating economic growth and development. The bibliometric evaluation comprised two important procedures, namely performance analysis and science mapping.

The contributions of this paper are as follows:

(1) This paper used a bibliometric method to analyze link between innovation, entrepreneurship, economic growth an development. Compared with previous studies, this method can more directly reflect the main content of innovation and entrepreneurship research.

(2) The literature on innovation in entrepreneurship for economic growth and development showed a significantly growing trend in the last five years.

(3) Analysing the total number of published documents, the United States and England have published more than $25 \%$ of the total works and are the leading countries in this topic;

(4) Refering to the main Web of Science Core Collection categories of interest for reserachers to publish their papers, these were: business, management and economics;

(5) Based on keyword trend network analysis, the contribution of innovation and entrepreneurship for economic growth and development became much more evident in research undertaken after 2015.

\section{ACKNOWLEDGMENT}

This work was cofinanced from the European Social Fund through Operational Programme Human Capital 2014-2020, project number POCU/380/6/13/125015 "Development of entrepreneurial skills for doctoral students and postdoctoral researchers in the field of economic sciences". 


\section{References}

1. Abbas, J., \& Sağsan, M. (2019). Impact of knowledge management practices on green innovation and corporate sustainable development: A structural analysis. Journal of cleaner production, 229, 611-620.

2. Baregheh, A., Rowley, J., \& Sambrook, S. (2009). Towards a multidisciplinary definition of innovation. Management decision.

3. Bolukbas, U., \& Guneri, A. F. (2018). Knowledge-based decision making for the technology competency analysis of manufacturing enterprises. Applied Soft Computing, 67, 781-799.

4. Carlson, C. R., \& Wilmot, W. W. (2006). Innovation: The five disciplines for creating what customers want. Currency.

5. Chen, F. W., Fu, L. W., Wang, K., Tsai, S. B., \& Su, C. H. (2018). The influence of entrepreneurship and social networks on economic growth - from a sustainable innovation perspective. Sustainability, 10(7), 2510.

6. Cho, Y. H., \& Lee, J. H. (2018). Entrepreneurial orientation, entrepreneurial education and performance. Asia Pacific Journal of Innovation and Entrepreneurship.

7. Dhahri, S., \& Omri, A. (2018). Entrepreneurship contribution to the three pillars of sustainable development: What does the evidence really say? World Development, 106, 64-77.

8. Dhamija, P., \& Bag, S. (2020). Role of artificial intelligence in operations environment: a review and bibliometric analysis. The TQM Journal.

9. Dias, Á., Silva, G. M., Patuleia, M., \& González-Rodríguez, M. R. (2020). Developing sustainable business models: local knowledge acquisition and tourism lifestyle entrepreneurship. Journal of Sustainable Tourism, 1-20.

10. Elliott, C., Mavriplis, C., \& Anis, H. (2020). An entrepreneurship education and peer mentoring program for women in STEM: mentors' experiences and perceptions of entrepreneurial self-efficacy and intent. International Entrepreneurship and Management Journal, 16(1), 43-67.

11. Gaviria-Marin, M., Merigó, J. M., \& Baier-Fuentes, H. (2019). Knowledge management: A global examination based on bibliometric analysis. Technological Forecasting and Social Change, 140, 194-220.

12. Gîrneaţăă, A., \& Mascu, M. (2014). Development discrepancies between Western and Eastern EU countries: a statistical analysis of textile and apparel clusters. In Proceedings of the 8th International Management Conference "Management challenges for the sustainable development", Bucharest, Romania (pp. 434-442).

13. Gora, A. A. (2019). The Link Between Decision Making Process and Performance: A Bibliometric Analysis. Management and Economics Review, 4(2), 177-191.

14. Katzy, B., Turgut, E., Holzmann, T., \& Sailer, K. (2013). Innovation intermediaries: a process view on open innovation coordination. Technology Analysis \& Strategic Management, 25(3), 295-309.

15. Kibler, E., Wincent, J., Kautonen, T., Cacciotti, G., \& Obschonka, M. (2019). Can prosocial motivation harm entrepreneurs' subjective well-being? Journal of business venturing, 34(4), 608-624.

130 Review of International Comparative Management

Volume 22, Issue 1, March 2021 
16. Kim, J., Kang, S., \& Lee, K. H. (2019). Evolution of digital marketing communication: Bibliometric analysis and network visualization from key articles. Journal of Business Research.

17. Kim, K. C., ElTarabishy, A., \& Bae, Z. T. (2018). Humane entrepreneurship: How focusing on people can drive a new era of wealth and quality job creation in a sustainable world. Journal of Small Business Management, 56, 10-29.

18. Malecki, E. J. (2018). Entrepreneurs, networks, and economic development: A review of recent research. Reflections and extensions on key papers of the first twenty-five years of advances.

19. Porter, M. E., \& Stern, S. (2001). Innovation: location matters. MIT Sloan management review, 42(4), 28.

20. Schilling, M. A., \& Shankar, R. (2019). Strategic management of technological innovation. McGraw-Hill Education.

21. Sergi, B. S., Popkova, E. G., Bogoviz, A. V., \& Ragulina, J. V. (2019). Entrepreneurship and economic growth: the experience of developed and developing countries. In Entrepreneurship and Development in the 21st Century. Emerald publishing limited.

22. Shu, R., Ren, S., \& Zheng, Y. (2018). Building networks into discovery: The link between entrepreneur network capability and entrepreneurial opportunity discovery. Journal of Business Research, 85, 197-208.

23. Stam, E., \& van de Ven, A. (2019). Entrepreneurial ecosystem elements. Small Business Economics, 1-24.

24. Teixeira, S. J., Casteleiro, C. M. L., Rodrigues, R. G., \& Guerra, M. D. (2018). Entrepreneurial intentions and entrepreneurship in European countries. International Journal of Innovation Science.

25. Tidd, J., \& Bessant, J. R. (2020). Managing innovation: integrating technological, market and organizational change. John Wiley \& Sons.

26. Tran, B. X., Vu, G. T., Ha, G. H., Vuong, Q. H., Ho, M. T., Vuong, T. T., ... \& Ho, R. (2019). Global evolution of research in artificial intelligence in health and medicine: a bibliometric study. Journal of clinical medicine, 8(3), 360.

27. Trifu, A. E., Girneata, A., \& Potcovaru, M. (2014). Influence of Natural Factors upon the Organization Activities. Revista de Management Comparat International, 15(4), 487.

28. Trifu, A. E., Gîrneață, A., \& Potcovaru, A. M. (2015). The Impact of Regulations upon the Startup of New Businesses. Economia: Seria Management, 18, 49-59.

29. Vallaster, C., Kraus, S., Lindahl, J. M. M., \& Nielsen, A. (2019). Ethics and entrepreneurship: A bibliometric study and literature review. Journal of Business Research, 99, 226-237.

30. Van Eck, N. J., \& Waltman, L. (2013). VOSviewer manual. Leiden: Univeristeit Leiden, 1(1), 1-53.

31. Verdin, P., \& Tackx, K. (2015). Are You Creating or Capturing Value? A dynamic framework for sustainable strategy. $M-R C B G$ Working Paper Series, 36, 1-19.

32. Yun, J. J., Won, D., \& Park, K. (2018). Entrepreneurial cyclical dynamics of open innovation. Journal of Evolutionary Economics, 28(5), 1151-1174. 